\title{
Epidemiological Profile and Detection of Resistance Genes in Bloodstream Infection in Cancer Patients: High Occurrence of Metallo- $\beta$-lactamases in Enterobacteriales
}

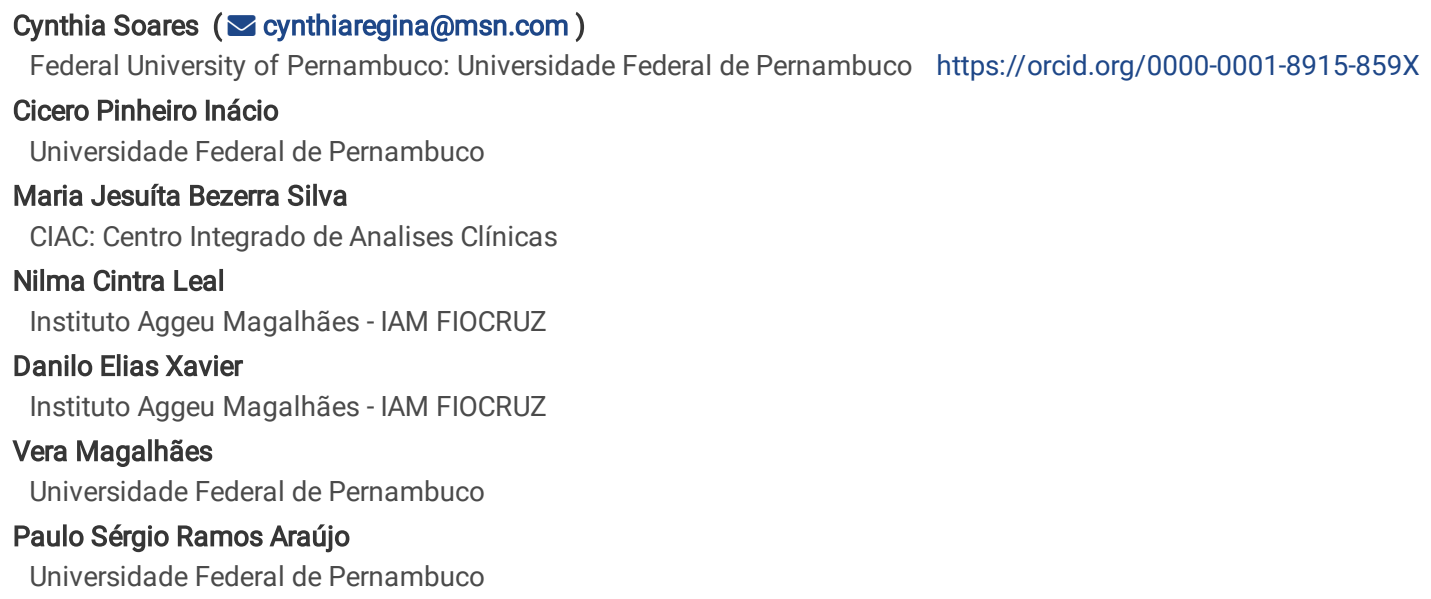




\section{Abstract}

Bloodstream infections remain one of the most common major complications in cancer patients. The aim of the study was to describe the etiology, phenotypic and molecular epidemiology of ICS isolates from cancer patients. Method: identification and the resistance profile were carried out using the automated biochemical method Vitek $2 \AA$. The presence and genes resistant to carbapenemases $b / a_{\mathrm{IMP}}, b / a_{\mathrm{VIM}}, b / a_{\mathrm{GIM}}, b / a_{\mathrm{SIM}}, b / a_{\mathrm{SPM}}, b / a_{\mathrm{KPC}}, b / a_{\mathrm{NDM}}, g e n e s$ oxacilinase $b / a_{\mathrm{OXA}-48}, b / a_{\mathrm{OXA}-58}$, and the presence of ESBL genes b/a ${ }_{\mathrm{SHV}}, b / a_{\mathrm{CTX}}, b / a_{\mathrm{TEM}}$ for Gram-negatives, as well as, $m e c A$, vanA and vanB for Grampositives were investigated in blood culture isolates. Result: Escherichia coli and Klebsiella pneumoniae were the most frequent pathogens. The serine- $\beta$ lactamase gene $b / a_{0 X A-48}$ was the most frequent, followed by M $\beta \mathrm{L} b / a_{\mathrm{SIM}}$. bla $a_{\mathrm{TEM}}$ and $b / a_{\mathrm{CTX}}$ were the most common among ESBL. The mecA and $v a n A$ genes were found in Staphylococcus spp. and Enterococcus faecium, respectively. Candida spp showed high resistance to voriconazole and fluconazole. Conclusion: measures to prevent and control the spread of resistance genes are essential to reduce the risks of morbidity and mortality.

\section{Introduction}

Bloodstream infections (ICS) are considered serious complications in cancer patients, especially during chemotherapy. Infections by Gram-negative agents are more frequent in this population, especially when in the course of febrile neutropenia ${ }^{1,2,3}$.

Gram-negative bacillus (BGN) ICS has been documented in several countries such as India ${ }^{4}$, Australia ${ }^{5}$, Italy ${ }^{6}$, Turkey $^{7}$, China $^{8}$ and Brazil ${ }^{9}$.

Most of these organisms develop resistance to antimicrobial agents, reducing the therapeutic options available and this issue has been considered one of the ten threats to global health ${ }^{10}$. Escherichia coli and Klebsiella pneumoniae have been identified as the main agents of resistant multidrug infections (MDR) in environments related to health care ${ }^{7,11}$. BGN producers of extended spectrum $\beta$-lactamase (ESBL) has emerged and is considered a serious threat to antimicrobial treatment ${ }^{12}$, and has been associated with increased mortality in cancer patients ${ }^{13,14,15,16,17,18}$.

Klebsiella pneumoneae carbapenemases (KPC) and New Delly metalo- $\beta$-lactamases (NDM) represent two important families of carbapenemases, which confer resistance to almost all molecules and have been reported worldwide. Several countries have detected the occurrence of BGN, carrying $b / a_{\mathrm{KPC}}, b / a_{\mathrm{NDM}}$, bla $a_{\text {OXA-48-like }}$ or bla $a_{\text {VIM }}$ genes, and showing high resistance to antibiotics ${ }^{19}$.

The aim of the study was to describe the etiology, phenotypic and molecular epidemiology of the ICS isolates from cancer patients.

\section{Materials And Methods}

\section{Collection and analysis of clinical isolates}

Clinical isolates were obtained from blood samples of patients admitted to the Pernambuco Cancer Hospital, Recife, Brazil, during the period 2019 to 2020. The prospective study included 45 patients aged $\geq 18$ years after consent. The study was approved by the Research Ethics Committee of the Pernambuco Cancer Hospital, CAEE (16285219.5.0000.5205).

Blood samples were collected in blood culture flasks which were subsequently incubated by Bactec9095® (Becton Dickinsion, USA) with up to 5 days of incubation. The identification and Antimicrobial Susceptibility Test (AST) of bacterial isolates were performed by biochemical tests using the automated system, using the Vitek 2 platform (bioMérieux, Marcyl'Etoile, France) and interpreted according to the Brazilian Committee on Antimicrobial Susceptibility Testing manual (BrCAST). The identification and antifungal susceptibility test (AFST) were performed by biochemical method and microdilution by the minimum antifungal concentration, interpreted according to the CLSI M27-A3/S4 Reference Method for Antifungal Susceptibility Test.

\section{Definition}

Resistant multidrug (MDR) was defined as a bacterial isolate, which is resistant to one or more antibiotics in three or more classes of antimicrobial agents.

ICS was defined as the isolation of blood from one (monomicrobial) or more (polymicrobial) organisms.

\section{Broth Microdilution Identification and Antifungal Susceptibility Test (AFST)}

The antifungal susceptibility test, in vitro, was performed according to the methods described in documents M27-A3 and M27-S4 of the Clinical and Laboratory Standards Institute 20,21 . For standardization of the experiment, the reference strain ATCC 90028 (C. albicans) was used. For the test, the RPMI 1640 medium (Sigma-Aldrich, USA) buffered with morpholino propane sulfonic acid, pH $7.0 \pm 0.1$ (MOPS; 0.165 mol.L-1; Sigma-Aldrich) was used. Yeasts were evaluated for their susceptibility profile to fluconazole, Amphotericin B, voriconazole, caspofungin, micafungin and anidulafungin.

The yeasts were kept on Sabouraud Dextrose Agar (SDA) and incubated for 24 hours at $37^{\circ} \mathrm{C}$. Suspensions of the isolates were prepared in $0.85 \%$ saline, with the inoculum concentration adjusted by a spectrophotometer with a wavelength of $530 \mathrm{~nm}$, reflecting $90 \%$ of the transmittance. Then, the initial suspension was diluted to a concentration of 2-5,103 cells/mL in RPMI 1640. 96-well flat-bottomed micro-titration plates (TPP; Trasadingen, Switzerland) were used. The inoculum was added to the wells containing the drug solution to be tested, and the plates incubated at $37^{\circ} \mathrm{C}$ for $24-48 \mathrm{~h}$. The Minimum Inhibitory Concentrations (MICs) were determined with $100 \%$ inhibition for amphotericin B and $<50 \%$ in relation to the control well for fluconazole and voriconazole.

\section{Extraction of fungal DNA from cultures}


The DNA was extracted according to the protocol of Inácio et al., (2016) 22 , using the extraction buffer (CTAB 2\%, NaCl $1.5 \mathrm{M}, 100 \mathrm{mM}$ Tris-HCl, $20 \mathrm{mM}$ EDTA, polyvinylpyrrolidone $1 \%$ ) previously heated to $65^{\circ} \mathrm{C}$. The cell wall was broken through mechanical agitation (speed $5.5 \mathrm{~m} / \mathrm{s}$ for 30 seconds) in FastPrep ${ }^{\circledR}$ (BIO 101, Farmingdale, New York, USA) and incubated for 10 minutes at $65^{\circ} \mathrm{C}$. The DNA was recovered from a sequential treatment based on alcohol-isoamyl chloroform (24: 1), isopropanole ethanol (70\%). Finally, $50 \mu \mathrm{l}$ of MiliQ autoclaved water was added, and the sample was incubated at $37^{\circ} \mathrm{C}$ for $20 \mathrm{~min}$ for $\mathrm{DNA}$ elution. The extraction products were assembled in parafilm ( $5 \mu \mathrm{L}$ of the extraction product, $2 \mu \mathrm{L}$ GLB and $2 \mu \mathrm{L}$ GelRed), using the Lambda DNA marker as standard. The DNA was subjected to electrophoresis on 1.5\% agarose gel, in a horizontal electrophoresis tank, containing the Tris-Acetate-EDTA (TAE) buffer, with a voltage of $100 \mathrm{v}$ for $20 \mathrm{~min}$. Subsequently, the DNA was analyzed for quality and quantity in a transilluminator. The genomic material was kept at $4^{\circ} \mathrm{C}$ until the time of analysis.

\section{Identification of fungal isolates}

The species were identified from the partial sequencing of the D1/D2 domain of the LSU (28S) region of the rDNA using primers NL1 (5'GCATATCAATAAGCGGAGGAAAAG - 3') and NL4 (5'- GGTCCGTGTTTCAAGACGG - 3') ${ }^{23}$. The sequencing samples had the PCR products purified (GenJET PCR Purification - Fermentas, UK), and the sequencing was performed on the Sequencing Platform-LABCEN / CCB (UFPE), according to internal protocols of the partner laboratory.

\section{Identification and Antimicrobial Susceptibility Test (TSA)}

The identification and antimicrobial susceptibility test (TSA) were carried out by phenotypic methods by automation. The automated identification tests $\left(V_{i t e k}{ }^{\circledR}\right.$ ) based on the fermentation of carbohydrates, followed the interpretation of the Clinical and Laboratory Standards Institute (CLSI) manual, and the TSA interpretation followed the Brazilian Committee on Antimicrobial Susceptibility Testing (BrCAST) protocol for interpretation of the results.

\section{Extraction of plasmid and chromosomal DNA from bacterial isolates}

All bacterial isolates were collected from positive blood cultures and subjected to DNA extraction and detection of resistance genes. From the cultures of the isolates, on BHI agar, the DNA was extracted using the PROMEGA ReliaPrep ${ }^{\mathrm{T} M}$ kit (Promega ${ }^{\circledR}$, São Paulo, Brazil) according to the manufacturer's protocol. The DNA was eluted in $50 \mu \mathrm{L}$ of nuclease-free water. An aliquot of the extracted DNA was quantified in NanoDrop 2000/2000c Spectrophotometer (Thermo Fisher Scientific), in order to verify the efficiency, purity and yield of the extraction. Then it was analyzed by electrophoresis on $1 \%$ agarose gel and stained with ethidium bromide.

\section{Detection of resistance genes in Gram-negative bacterial isolates}

DNA amplification using the Polymerase Chain Reaction (PCR) technique was performed on BioRad equipment (System, Applied Biosystems ${ }^{\circledR}, \mathrm{CA}$, using 10 $\mu \mathrm{L}$ (1.25U / reaction) TopTaq Master Mix Kit (Qiagen ${ }^{\circledR}$, USA) using $10 \mu \mathrm{M}$ of each primer, $200 \mu \mathrm{M}$ of each dNTP (10mM of each), 1x TopTaq PCR Buffer containing $15 \mathrm{mM} \mathrm{MgCl} 2,1 \times$ coralLoad, ultra-pure water and $2 \mu \mathrm{L}$ of DNA Thermocycling conditions were established according to the studied resistance genes reference strains such as, A. baumannii (ATCC 19606), P. aeruginosa (ATCC 27853), K. pneumoniae (ATCC 13882), E. coli (ATCC 25922), Serratia marcescens (ATCC 14756), Salmonella enterica (ATCC 35640) were provided by the Department of Microbiology of the Aggeu Magalhães Institute (IAM) Fundação Oswaldo Cruz (FIOCRUZ).

A conventional PCR assay was performed for 55 isolates recovered from 45 patients to detect three families of ESBL genes. The detection of $b / a_{\text {SHV }}, b / a_{\mathrm{TEM}}$, $b / a_{\text {CTX-M }}$ resistance genes was performed in all Gram-negative bacterial isolates. And the detection of the $m c r-1$ gene was carried out in everyone who was resistant to multiple drugs. PCR for detection of ESBL was performed using the following protocol for amplification; initial denaturation $95^{\circ} \mathrm{C}$ to 5 minutes, followed by 30 cycles of denaturation $95^{\circ} \mathrm{C}$ to 1 minute, annealing $60^{\circ} \mathrm{C}$ to 1 minute and extension $72^{\circ} \mathrm{C}$ to 1 minute. A final extension step was performed at $72^{\circ} \mathrm{C}$ at 10 minutes, for each of the studied genes.

And eight families of the metallo- $\beta$-lactamase $(\mathrm{M} \beta \mathrm{L})$ genes, (b/a $a_{\mathrm{KPC}}, b / a_{\mathrm{GES}}, b / a_{\mathrm{NDM}}, b / a_{\mathrm{IMP}}, b / a_{\mathrm{VIM}}, b / a_{\mathrm{SPM}}$, bla $a_{\mathrm{GIM}}$ and $\left.b / a_{\mathrm{SIM}}\right)$ were investigated for the detection of carbapenemases, performed in all Gram-negative bacterial isolates. Using the following protocol for amplification; initial denaturation $95^{\circ} \mathrm{C}$ at 5 minutes, followed by 25 cycles of denaturation $95^{\circ} \mathrm{C}$ at 1 minute, ringing at 1 minute (according to the ringing temperature for each gene) and extension $72^{\circ} \mathrm{C}$ at 1 min. A final extension step was performed at $72^{\circ} \mathrm{C}$ at 10 minutes, table 1 .

The strains were also subjected to PCR to detect class D carbapenemases, such as oxacillinase (b/a OXA-48, $_{1}$ b/aXA-58), using the following protocol for amplification; initial denaturation $94^{\circ} \mathrm{C}$ at 5 minutes, followed by 30 cycles of denaturation $94^{\circ} \mathrm{C}$ at 45 seconds, annealing $52^{\circ} \mathrm{C}$ at 45 seconds and extension $72^{\circ} \mathrm{C}$ at 1 minutes. A final extension step was performed at $72^{\circ} \mathrm{C}$ at 6 minutes, as shown in table 1 .

\section{PCR conditions for identification of the $\mathbf{m c r}-\mathbf{1}$ gene}

The investigation of the $m c r-1$ gene was performed using the primers described by Lima et al., $(2017)^{31}$. The amplification reactions were prepared in a volume of $25 \mu \mathrm{L}$ per tube, comprising: $1 \mu \mathrm{L}$ of genomic DNA, 1.0U of the Taq DNA polymerase enzyme (Promega), $2 \mathrm{mM}$ of each dNTP, $2.5 \mathrm{mM}$ of MgCl2 and $3.5 \mathrm{pmol}$ of the primers. The amplification was performed under the following thermal cycling conditions: $94^{\circ} \mathrm{C}$ for 10 minutes followed by 30 cycles of $94^{\circ} \mathrm{C}$ for 30 seconds, $58^{\circ} \mathrm{C}$ for 30 seconds and $72^{\circ} \mathrm{C}$ for 2 minutes, with a final extension of $72^{\circ} \mathrm{C}$ for 10 minutes. The PCR products were visualized on a $1 \%$ agarose gel stained with ethidium bromide.

Detection of resistance genes in Gram-positive bacterial isolates 
All Gram-positive isolates, mecA, vanA, vanB resistance genes were detected using reference strains of organisms, S. aureus (ATCC 29213 and 25923), Streptococcus pneumoniae (ATCC 6305) S. epidermides (ATCC 12228), E. faecalis (ATCC 29212), E. faecium (ATCC 19434). The primers mecA-F (5'AAAACTAGGTGTTGGTGAAGATATACC -3 ') and mecA-R (5'- GAAAGGATCTGTACTGGGTTAATCAG -3') with a fragment size of 147pb, the primers VanA-F (5'CATGACGTAATCGGTAAAATC-3') and VanA-R (5'-ACCGGGCAGRGTATTGAC-3') with fragment size of 732 bp. And the primers VanB-F (5'-

CATGATGTGTCGGTAAAATC -3 ') and VanB-R (5'-ACCGGGCAGRGTATTGAC-3') with 635 bp fragment size. Using the following protocol for amplification; initial denaturation $95^{\circ} \mathrm{C}$ to 5 minutes, followed by 30 cycles of denaturation $95^{\circ} \mathrm{C}$ to 1 minute, annealing $60^{\circ} \mathrm{C}$ to 1 minute and extension $72^{\circ} \mathrm{C}$ to 1 minute. A final extension step was performed at $72^{\circ} \mathrm{C}$ for 10 minutes.

The amplified PCR products were stained with ethidium bromide and visualized by electrophoresis on 1\% agarose gels, using the System L-Pix EX photographic documentation system (LoccusBiotechnology, Brazil).

The consensus strings were edited using the Sequencher 4.7 program and then submitted to the BLAST tool from GenBank (National Center of Biotechnology Information, http://www.ncbi.nlm.nih.gov) to search for similar strings. The obtained sequences were aligned with confidence sequences deposited in the database and analyzed phylogenetically with the aid of the MEGA-x program.

\section{Results}

\section{Detection of pathogens in the bloodstream}

Were recovered 55 clinical isolates from blood culture samples from 45 cancer patients, 38 Gram-negative, 13 Gram-positive and four yeast. Of the BGN, the most frequent were Escherichia coli $(36,8 \%)$ and Klebsiella pneumoniae (28,9\%). Among the Gram-positive, the most frequent were Staphylococcus aureus $(38,5 \%)$ and Staphylococcus epidermidis (23\%). Four patients had infections due to Candida species (graphic 1). Polymicrobial bloodstream infection was identified in three cases. As Escherichia coli, Klebsiella pneumonia, Candida parapslosis. Coagulase negative Staphylococcus (SCN) and Candida tropicalis. And finally, Pseudomonas aeruginosa, Escherichia coli and Klebsiella pneumoniae.

\section{Antimicrobial susceptibility profile in bacterial isolates}

Among gram-negative bacteria, most showed resistance to ampicillin (63,15\%), cefepime (39,4\%), ciprofloxacin (34,2\%) and cefuroxime (29\%). It was possible to observe a high percentage of resistance to ampicillin in Klebsiella spp 100\% (11/11) and Escherichia coli 78,6\% (11/14) table 2. 4th generation cephalosporin was the class of antibiotics that showed greater resistance in Acinetobacter baumannii (66\%), Pseudomonas aeruginosas (42,8\%), Klebsiella spp (36,3\%) and Escherichia coli (28,5\%). As cefuroxime, 2nd generation cephalosporins showed resistance in Serratia marcencens (100\%), Salmonella spp (100\%), Klebsiella spp (36,3\%) and Escherichia coli $(28,5 \%)$ table 3. In the fluoroquinolone class, the percentage of resistance to ciprofloxacin ranged from $27,2 \%$ Klebsiella spp to $66 \%$ in Acinetobacter baumannii (table 3). The quinolone class nalidixic acid antibiotic showed greater resistance in Escherichia coli $(42,8 \%)$.

In general, when analyzing the percentage of sensitivity of BGN, we observed that $78,9 \%$ were sensitive to amikacin and meropenem, and $76,3 \%$ to gentamicin and $68,4 \%$ to ertapenem.

In gram-positive bacteria the highest resistance rate was to oxacillin $6 / 13(46,1 \%)$ and erythromycin $5 / 13(38,4 \%)$, high resistance to penicillin and gentamicin $4 / 13$ was also observed $(30,7 \%)$ (table 2$)$.

Oxacillin resistance was observed in Staphylococcus aureus 3/5 (60\%) Staphylococcus Coagulase Negative 3/4, the latter being identified as Staphylococcus epidermidis (75\%). From the macrolides class, resistance to erythromycin was observed in Staphylococcus epidermidis 3/3 (100\%) and Staphylococcus aureus $2 / 5$ (40\%). Resistance to penicillin and gentamicin aminoglycoside were 2/5 (40\%) and 1/3 Staphylococcus epidermides (33,3\%) and 1/1 coagulase negative Staphylococcus (100\%) table 3.

Resistance to clindamycin, sulfamethoxazole / trimethoprim and levofloxacin were observed in S. aureus and S.epidermidis. Resistance to amikacin and vancomycin was observed only in Enterococcus faecium (table 3).

Of the 55 isolates, 28 were MDR $(50,9 \%)$, while six $(10,9 \%)$ bacterial isolates were sensitive to all antibiotics tested and three (5,45\%) of the isolated pathogens were resistant to all classes of antibiotics tested.

\section{Detection of bacterial resistance genes}

The detection of a broad-spectrum $\beta$-lactamases gene was observed in $28 / 38(73,7 \%)$ gram-negative isolates. The $b / a_{\text {TEM }}$ gene was detected in 22 isolates, including 10 E. coli, 5 K. pneumoniae, 2 P. aerguginosa and 2 A. baumannii. The bla CTX-M gene was detected in 16 isolates, 7 K. pneumoniae, 5 E. coli and 2 P. aeruginosa. The bla $\mathrm{SHV}_{\mathrm{V}}$ gene was detected in only 2 isolates, 1 E. coli and 1 A. baumanii (table 4).

High frequency of $36 / 38$ metallo- $\beta$-lactamases genes $(94,7 \%)$ were detected in the isolates. The gene most often found in the study was a serine-b-lactamase bla OXA-48 $_{31 / 38}$ (81,5\%), being E. coli (12), K. pneumoniae (8), P. aeruginosa (5), Serratia marcescens (2), A. baumannii (2), and in the species of P. alcaligens and Salmonella spp (1).

Then the bla $\mathrm{SIM}_{\mathrm{M}}$ gene $27 / 38$ (71\%), E. coli (10), K. pneumoniae (9), P aeruginosa (6), P. alcaligens (1) and Serratia marcescens (1). The detection of the bla $a_{\mathrm{GES}}$ gene was 21/38 (55,2\%), E. coli (8), K. pneumoniae (7), P. aeruginosa (3), A. baumannii (1), Serratia marcescens (1) and Klebsiella oxytoca (1). The bla ${ }_{\mathrm{NDM}}$ 
15/38 gene (39,4\%) was detected in E. coli (7), K. pneumoniae (6), P. aeruginosa (1) and Serratia marcescens (1). The bla $\mathrm{KPC} 11 / 38 \mathrm{gene}(28,9 \%)$ was detected in E. coli (5), K. pneumoniae (3), P. aeruginosa (2) and S. marcescens (1). The bla SPM $7 / 38$ gene (26,3\%) was found in 7 isolates, $K$. pneumoniae (2), P. aeruginosa (2), Pseudomonas alcaligens (1), A. baumannii (1) and Serratia marcescens (1). The bla $a_{0 X A-58} 10 / 38$ gene (26,3\%) was detected in E. coli (7), and in the species of $K$. pneumoniae, A. baumannii and Serratia marcescens (1). The bla $\mathrm{VIM}_{\mathrm{M}} 7 / 38 \mathrm{gene}(18,4 \%)$, E. coli (5) and K. pneumoniae (2). The bla was detected in 6 isolates, being E. coli (5) and K. pneumoniae (1). The same isolate can carry more than one gene (table 4). The mcr-1 gene was not detected in any of the tested isolates.

Of the Gram-positive bacteria, five were $S$. aureus, three were coagulase-negative Staphylococcus (three were $S$. epidermidis, one $S$ warneri and one Streptococcus salivarus, an unidentified SCN), and two Enterococcus spp. The presence of the mecA gene was detected in 6/13 (46,15\%) isolates, Staphylococcus aureus and coagulase negative Staphylococcus (S. epidermidis) and Enterococcus faecalis. Only one Enterococcus faecium isolate had the vanA gene (1/13) $(7,7 \%)$. The vanB gene was not detected in any of the studied isolates (table 4).

\section{Detection of fungal ICS}

Four species of Candida spp. were found in this population. Resistance to fluconazole was observed in 3/4 isolates. One Candida tropicalis isolate presented caspofungin as a sensitive dose dependent. All species showed resistance to voriconazole (table 5).

\section{Discussion}

The phenotypic and molecular characteristics of 55 clinical isolates rescued from blood cultures of patients with malignant neoplasms, allowed to observe a higher frequency of BGN $(69 \%)$ greater than CGP $(23,63 \%)$, in addition to $7,2 \%$ of yeasts. BGNs have been implicated as the main cause of ICS in cancer patients 32,33 .

The most commonly found BGN were Escherichia coli (25,4\%), Klebsiella pneumoniae (20\%) and Pseudomonas aeruginosa (12,7\%), as well as reported in recent studies ${ }^{34,35,36,37}$. Evidence has suggested the phenomenon of bacterial translocation, where enterobacteria cross the intestine wall, migrating into the bloodstream, causing bacteremia in patients receiving cancer chemotherapy ${ }^{38,39}$, explaining in the greater frequency of this group of bacteria is part of the etiology of bloodstream infection.

The epidemiology of the occurrence of bacteremia in cancer patients has changed over time and has been characterized by a change in the profile from gramnegative bacteria (1960s to 1970s) to gram-positive bacteria (1980s). Gram-negative bacteria have been predominant as the main agents of bloodstream infections in cancer patients in the last two decades on the global stage ${ }^{40,41}$.

According to the Antimicrobial Surveillance Program (SENTRY) S. aureus and E. coli have been identified as the predominant pathogens of ICS in the world for the past 20 years ${ }^{42}$. Our study showed a higher frequency of coagulase-negative Staphylococcus and Staphylococcus aureus among gram-positive bacteria, corroborating with other studies ${ }^{16,7,43}$.

The occurrence of polymicrobial infections in three cases was associated with neutropenia and the presence of a catheter. In two cases, they were associated with MDR and in one case, an operative procedure was performed. Presence of neutropenia, recent invasive procedures and devices have been identified as risk factors for polymicrobial infection of the bloodstream, highlighting that MDR isolates have been more commonly found in polymicrobial infection ${ }^{44,45}$. Polymicrobial infections were responsible for $5,45 \%(3 / 55)$ of these cases, corroborating the study of ICS in cancer patients in India ${ }^{46}$.

The occurrence of $\beta$-lactamase resistance genes has been reported in isolates of polymicrobial bloodstream infection from a patient with acute myeloid leukemia in Brazil, including bla $a_{\mathrm{TEM}}$ e bla $a_{\mathrm{SIM}}$ in P. aeruginosa, bla $\mathrm{TEM}_{\mathrm{TEM}}, b / a_{\mathrm{CTX}}$ and bla $a_{\mathrm{OXA}-48}$ in E coli, bla $a_{\mathrm{CTX}}, b / a_{\mathrm{KPC}}, b / a_{\mathrm{NDM}}, b / a_{\mathrm{SIM}}$ and $b / a_{0 X \mathrm{~A}-48}$ in $K$. pneumoniae and bla OXA-48 in $A$. baumannii ${ }^{47}$.

BGNs showed greater resistance to aminopenicillins, fourth generation cephalosporins, fluoroquinolones, second and first generation cephalosporins and aminoglycosides, in agreement with the results of a study in India carried out with 66 cases of bloodstream infection ${ }^{40}$. Increased resistance to carbapenems, combinations of beta-lactamase inhibitors, beta-lactamase, aminoglycosides, fluoroquinolones and cephalosporins (including high resistance to cefepime) has been observed ${ }^{41}$.

Our study showed $(46,15 \%)$ of MRSA, including Staphylococcus aureus and Staphylococcus coagulase negative (MRCoNS) species, respectively. Recent studies have observed resistance to methicillin in Staphylococcus spp ranging from $38,4 \%$ to $93 \% 48,7$. Resistance to methicillin has been more frequent in SCN compared to $S$. aureus ${ }^{49,50}$.

And the occurrence of vancomycin-resistant Enterococcus was 7,7\%, similar to that found by Bhat et al., $(2021)^{40}$. The prevalence of vancomycin-resistant enterococci (VRE) has become stable or decreasing after $2012^{42}$.

MDR infections are worrisome phenomena, particularly in cancer patients ${ }^{17}$, due to low therapeutic options and, consequently, a higher risk of mortality ${ }^{51}$. Among the isolated pathogens, the general frequency of MDR was $50,9 \%(28 / 55)$. The main isolated MDR bacteria were E. coli and K. pneumoniae, which present results in agreement with other studies ${ }^{49,41}$.

The detection of ESBL resistance genes was $73,7 \%$, presenting data similar to those found by other studies in this same population of cancer patients. Mexico

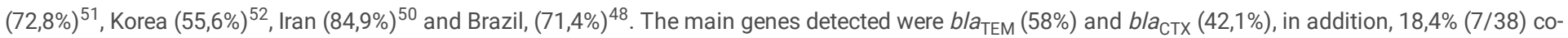


housed the bla $a_{\mathrm{TEM}}$ and $b / a_{\mathrm{CTX}}$ genes, corroborating with other studies ${ }^{53,36}$.

A high prevalence of $M \beta L(94,7 \%)$ was detected, which seems to express a much higher frequency than those presented by other studies ${ }^{51,54}$. Carbapenemresistant enterobacteriaceae (CRE) has been increasingly prevalent in cancer patients and associated with ineffective empirical therapy ${ }^{55}$. The mechanism of resistance to carbapenems is hydrolysis by carbapenemases that are encoded in plasmids and are highly transmissible. Resistance to carbapenem can also be attributed to mutations or other modifications that alter the level of production or binding affinity of penicillin-binding proteins ${ }^{56}$. This problem reflects the use of different carbapenems in hospitals, in addition to varying according to geographic location ${ }^{56}$.

The most frequently detected carbapenemase was bla $a_{\text {XXA-48 }}(81,5 \%)$. A study from Egypt with cancer patients also found a high prevalence of $b / a_{0 X A-48}$ $(68,88 \%)^{54}$. Another study involving several European countries showed that E. coli and Klebsiella pneumoniae were the main producers of carbapenemases $\left(\right.$ KPC, NDM, OXA-48-like or VIM) ${ }^{19}$.

The frequency of the blaoxa-48 gene was detected in $70,83 \%$ and $92 \%$ in isolates of $P$. aeruginosa and $A$. baumannii, respectively in Iran ${ }^{57}$.

Other studies have reported the occurrence of genes that encode subgroups of OXA carbapenemases, including the $b / a_{0 X A-58}$ gene ${ }^{58,59}$. The OXA-48 enzyme leads to resistance to carbapenems, limiting therapeutic options, organisms that produce OXA-48 and are intrinsically resistant to colistin when infecting patients can be fatal, cause high mortality ${ }^{60}$.

We detected a high frequency of $b / a_{\text {SIM }} 27 / 38(71 \%)$ in enterobacteciales. The frequency of bla ${ }_{\text {SIM-1 }}$ in Egypt was $48 \%{ }^{61}$. And in Brazil, $66.6 \%$ were reported in human and animal samples ${ }^{62}$.

We highlight the presence of the bla ${ }_{\mathrm{SPM}}$ gene in Pseudomonas spp isolates, as has already been found ${ }^{28}$ and in $A$. baumanni ${ }^{63}$, who described the first

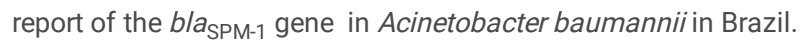

Although MRSA is frequent in ICS in the hospital population ${ }^{64}$, few studies mention the occurrence of MRSA in ICS of cancer patients ${ }^{65}$. The frequency of the mecA gene, in which all showed phenotypic resistance to methicillin, was $46,1 \%(6 / 13)$. However, the prevalence of MRSA in cancer patients in hospitals in Turkey was $50 \%$, harboring the $m e c A$ genotype ${ }^{66}$. The vanA gene was detected in an isolate of Enterococcus faecium rescued from the bloodstream of a patient with colon cancer, whose phenomenon of bacterial translocation through the permeability of the injured colon mucosa may have acted as a risk factor for the event ${ }^{67}$.

Candida species were found in four samples (7,2\%). Candida spp. is the most commonly isolated yeast in ICS ${ }^{68}$. Candida tropicalis was the most frequent species in our study, being commonly found in cancer patients ${ }^{69}$. Our study showed two concomitant bloodstream infections involving fungi and bacteria, one being Klebsiella pneumoniae, Escherichia coli and Candida parapsilosis. And another from SCN and Candida tropicalis. A fungal monoinfection was registered by Candida tropicalis. Bloodstream infections involving both bacteria and yeast have been documented ${ }^{70}$.

Our result showed resistance to voriconazole in all Candidas spp. The rate of azole resistance among $C$. tropicalis has been significant compared to rates of resistance to micafungin ${ }^{71}$. The antifungal caspofugin showed dose-dependent susceptibility in Candida tropicalis (1/4). Caspofungin has been reported to have potent activity against Candida spp. resistant to fluconazole ${ }^{72}$.

The growing scenario related to the emergence of Candida species resistant to fluconazole and voriconazole is a worrying scenario. A study in Australia warns of the emergence of azole resistance among $C$. tropicalis ${ }^{73}$. Voriconazole has been reported as an important agent in the treatment of hyaline fungi and effective for infections caused by Candida species, including those that are resistant to fluconazole ${ }^{74}$.

Azole resistance can arise through several mechanisms, including overexpression or alteration of the drug target, positive regulation of drug transporters or cellular alterations that reduce drug toxicity or allow tolerance to drug-induced stress. The activation of membrane-associated efflux pumps that modulate resistance through $A B C$ transporters and main facilitator (MFS), allowing resistance to multiple drugs ${ }^{75}$.

Thus, as the emergence of drug-resistant fungi, the combination of antibiotics with antifungals has been explored to enhance the treatment, as colistin could increase the antifungal activity of fluconazole $e^{76}$.

The worldwide dissemination of resistant isolates, combined with the few available therapeutic options, has negatively influenced the treatment and prognosis of patients ${ }^{77}$. Species of Candida albicans, especially emerging ones, have significantly influenced the clinical course of patients around the world. Currently, the most recent guidelines for the treatment of fungal infections have recommended fluconazole as a primary therapeutic option to combat these infections. However, there have been increasing reports of increased resistance inherent in this drug that can pose a global health threat ${ }^{78}$.

Antimicrobial resistance is of great concern mainly in the population group vulnerable to infections due to chemotherapy itself or due to factors attributed to the history of cancer. Measures to prevent and control the spread of resistance genes are essential to reduce the risks of morbidity and mortality.

\section{Abbreviations}

Bloodstream infections (ICS)

Gram-negative bacilli (BGN) 
Carbapenem-resistant enterobacteriaceae (CRE)

Coco Gram-positives (CGP)

Extended spectrum $\beta$-lactamase (ESBL)

Metallo- $\beta$-lactamase (MßL)

Resistant multidrug (MDR)

Klebsiella pneumoneae carbapenemases (KPC)

New Delly metalo- $\beta$-lactamases (NDM)

Polymerase Chain Reaction (PCR)

Staphylococcus aureus resistance to methicillin (MRSA)

Staphylococcus coagulase negative resistance to methicillin (MRCoNS)

\section{Declarations}

\section{Statements:}

- Financing

- Interest conflicts

- Availability of data and materials

- Code Availability

- Ethics approval

- Consent to participate

- Consent to publication

- Author Contribution Statement

- Acknowledgment

\section{Financing}

This work was supported by the Foundation for the Support of Science and Technology of the State of Pernambuco with the financial assistance of the Research Program for SUS (PPSUS), by APQ-0563- 4.01/17 in the basic research category.

\section{Interest conflicts}

All authors declare no conflict of interest.

\section{Availability of data and materials}

All data generated or analyzed during this study is included in this published article.

\section{Code Availability}

Not applicable

\section{Ethics approval}

Written informed consent for the publication of their clinical details was obtained from the patient's parents. A copy of the consent form is available for review by the Editor of this magazine. Written informed consent was given and maintained by the authors. This work was approved by the Research Ethics Committee of the Pernambuco Cancer Hospital (HCP) in which the work was carried out (CAAE: 16285219.5.0000.5205).

\section{Consent to participate}

Consent to participate was obtained by the patient or guardian in case of death, by signing the Informed Consent Form (ICF) approved by the CEP of the Cancer Hospital of Pernambuco, following resolution 466/12 of the National Health Council.

\section{Consent to publication}

Consent for publication was obtained by the patient, signing the Free and Informed Consent Term (ICF) approved by the CEP of the Pernambuco Cancer Hospital, following resolution $466 / 12$ of the National Health Council. 


\section{Author Contribution Statement}

PSRA and VMS conceived and designed surveys. CRPS, CPI and MJBS conducted experiments. NCL and DEX contributed new reagents or analytical tools, correction. CRPS wrote the manuscript. All authors read and approved the manuscript.

\section{Acknowledgment}

To the Microbiology Laboratory team for kindly providing some strains of controls used in the development of this work, we thank Maria Cândida Nascimento da Costa for her support in research and technical assistance.

\section{References}

1.Klastersky, J.; Ameye, L.; Maertns, J., et al. Bacteremia in febrile neutropenic cancer patients. Int J. Antimicrob Agent. 2007;30,51-59.

2.Cattaneo, C. Antoniazzi, F. Casari, S. et al. P. aeruginosa blood-stream infection among hematological patients: an old or new question? Ann Hematol. 2012;91(8),1299-1304

3.Aslan, S.; Citak, E. C.; Yis, R.; Degirmenci, S.; Arman, D. Bacterial Spectrum and antimicrobial susceptibility pattern of bloodstream infections in children with febrile neutropenia: experience of single center in southeast of Turkey. Indian J. Microbiol, 2012; 52(2),203-208.

4.Mandal, P. K.. Micro-organisms Associated with Febrile Neutropenia in Patients with Haematological Malignancies in a Tertiary Care Hospital in Eastern India. Indian J Hematol Blood Transfus. 2015;31(1):46-50.

5. Conn JR, Catchpoole EM, Runnegar N, Mapp SJ, Markey KA. Low rates of antibiotic resistance and infectious mortality in a cohort of high-risk hematology patients: A single center, retrospective analysis of blood stream infection. PLoS One. 2017;12(5): e0178059. doi: 10.1371 / journal.pone.0178059.

6. Di Blasi R, Cattaneo C, Lewis RE, Tumbarello M, Angelici L, Dragonetti G, et al. Febrile events in acute lymphoblastic leukemia: a prospective observational multicentric SEIFEM study (SEIFEM-2012/B ALL). Ann Hematol. 2018;97(5):791-798. doi: 10.1007/s00277-018-3252-6.

7.Mert D, Ceken S, Iskender G, Iskender D, Merdin A, Duygu F, Ertek M, Altuntas F. Epidemiology and mortality of bacterial bloodstream infections in patients with hematologic diseases. J Infect Dev Ctries. 2019;13:727-735. doi: 10.3855 / jidc.11457

8.Jiang AM, Shi X, Liu N, Gao H, Ren MD, Zheng XQ, Fu X, Liang X, Ruan ZP, Yao Y, Tian T. Nosocomial infections due to multidrug-resistant bacteria in cancer patients: a six-year retrospective study of an oncology Center in Western China. BMC Infect Dis. 2020;29;20(1):452. doi: 10.1186/s12879-020-05181-6.

9.Garrido MM, Garrido RQ, Cunha TN, Ehrlich S, Martins IS. Comparison of epidemiological, clinical and microbiological characteristics of bloodstream infection in children with solid tumours and haematological malignancies. Epidemiollnfect. 2019;8;147:e298. doi: 10.1017/S0950268819001845.

10.OPAS - Organização Pan-Americana da Saúde. Dez ameaças à saúde que a OMS combaterá em 2019. Brasília (DF). 2019. https://www.paho.org/bra/index.php?option=com_content\&view=article\&id=5848:dez-ameacas-a-saude-que-a-oms-combatera-em2019\&ltemid=875. Accessed 26 dezember 2020.

11.Castanheira M, DeshpandeLm, Mathai D, Bell Jm, Jones Rn, Mendes Re. Early dissemination of NDM-1- and OXA-181- producing Enterobacteriaceae in Indian hospitals: report from the SENTRY Antimicrobial Surveillance Program, 2006-2007. Antimicrob AgentsChemother. 2011;55:1274-8.

12. Paterson DL, Bonomo RA. Extended-spectrum beta-lactamases: a clinical update. Clin Microbiol Rev. 2005;18(4):657-86. doi: 10.1128/CMR.18.4.657686.2005

13.Ceken S, Iskender G, Gedik H, Duygu F, Mert D, Kaya AH, Altuntas F, Ertek M. Risk factors for bloodstream infections due to extended-spectrum $\beta$-lactamase producing Enterobacteriaceae in cancer patients. J Infect Dev Ctries. 2018;30;12(4):265-272. doi: 10.3855/jidc.9720.

14.Mitsuboshi S, Tsuruma N, Watanabe K, Takahashi S, Nakashita M, Ito A, Kobayashi K, Tsugita M. Does Quick Sepsis-Related Organ Failure Assessment Suggest the Use of Initial Empirical Carbapenem Therapy in Bacteremia Caused by Extended-Spectrum $\beta$-Lactamase-Producing Bacteria?: A Multicenter CaseControl Study. Jpn J Infect Dis. 2019;25;72(2):124-126. doi: 10.7883/yoken.JJID.2018.272.

15.Tohamy ST, Aboshanab KM, El-Mahallawy HA, El-Ansary MR, Afifi SS. Prevalence of multidrug-resistant Gram-negative pathogens isolated from febrile neutropenic cancer patients with bloodstream infections in Egypt and new synergistic antibiotic combinations. Infect Drug Resist. 2018;25;11:791-803. doi: 10.2147/IDR.S163293.

16.Calvo-Lon J, Landaverde DU, Ramos-Esquivel A, Villalobos-Vindas JM. Epidemiology and Outcomes of Bloodstream Infections in Patients With Solid Tumors in a Central American Population at Mexico Hospital, San Jose, Costa Rica. J Glob Oncol. 2018;4(4):1-6. doi: 10.1200/JG0.17.00058.

17.Cattaneo C, Di Blasi R, Skert C, et al. Bloodstream infections in haematological cancer patients colonized by multidrug-resistant bacteria. Ann Hematol. 2018;97(9):1717-1726. doi:10.1007/s00277-018-3341-6

18. Nham, E., Huh, K., Cho, SY, Chung, DR, Peck, KR, Lee, NY, \& Kang, Cl. Characteristics and clinical outcomes of extended-spectrum beta-lactamase-producing Klebsiella pneumoniae bacteria in cancer patients. Infection and chemotherapy. 2020;52(1),59-69. https://doi.org/10.3947/ic.2020.52.1.59 
19. Grundmann H, Glasner C, Albiger B, Aanensen DM, Tomlinson CT,. et al. Occurrence of carbapenemase-producing Klebsiella pneumoniae and Escherichia coli in the European survey of carbapenemase-producing Enterobacteriaceae (EuSCAPE): a prospective, multinational study. Lancet Infect Dis. 2017;17(2):153163. doi: 10.1016/S1473-3099(16)30257-2.

20.Clinical and Laboratory Standards Institute. (CLSI). Reference method for broth dilution antifungal susceptibility testing of yeasts; Third Edition. 2008, CLSI document M27-A3. Wayne, PA: Clinical and Laboratory Standards Institute.

21.Clinical and Laboratory Standards Institute. (CLSI). Reference method for broth dilution antifungal susceptibility testing of yeasts; fourth informational supplement. 2012, (Document M27-S4), Wayne: Clinical and Laboratory Standards Institute.

22.Inácio CP, Rocha AP, Barbosa RN, Oliveira NT, Silva JC, de Lima-Neto RG, Macêdo DP, Neves RP. (2016). Experimental white piedra: a robust approach to ultrastructural analysis, scanning electron microscopy and etiological discoveries. Exp Dermatol. 2016;25(1):79-81. doi: 10.1111/exd.12884.

23. Kurtzman, CP, \& Robnett, CJ (1997). Identification of clinically important ascomycete yeasts based on nucleotide divergence at the 5 'end of the large subunit ribosomal DNA (26S) gene. Journal of Clinic microbiology. 1997;35(5),1216-1223. https://doi.org/10.1128/JCM.35.5.1216-1223.1997

24.Menezes LC, Rocchetti TT, BauabKde C, Cappellano P, Quiles MG, Carlesse F, de Oliveira JS, Pignatari AC. Diagnosis by real-time polymerase chain reaction of pathogens and antimicrobial resistance genes in bone marrow transplant patients with bloodstream infections. BMC Infect Dis. 2013;5;13:166. doi: $10.1186 / 1471-2334-13-166$

25.Monteiro J, Widen RH, Pignatari AC, Kubasek C, Silbert S. Rapid detection of carbapenemase genes by multiplex real-time PCR. J AntimicrobChemother. 2012;67(4):906-9. doi: 10.1093/jac/dkr563.

26.Nithia N, Remitha R, Jayasree PR, Faisal M, ManishKumar PR. Analysis of beta-lactamases, blaNDM-1 phylogeny \& plasmid replicons in multidrug-resistant Klebsiella spp. from a tertiary care centre in south India. Indian J Med Res. 2017;146(1):38-45.doi: 10.4103 / ijmr.IJMR_31_16

27.Mendes RE, Kiyota KA, Monteiro J, Castanheira M, Andrade SS, Gales AC, Pignatari AC, Tufik S. Rapid detection and identification of metallo-betalactamase-encoding genes by multiplex real-time PCR assay and melt curve analysis. J ClinMicrobiol. 2007;45(2):544-7. doi: 10.1128/JCM.01728-06.

28.Poirel L, Héritier C, Tolün V, Nordmann P. Emergence of oxacillinase-mediated resistance to imipenem in Klebsiella pneumoniae. Antimicrob Agents Chemother. 2004;48(1):15-22. doi: 10.1128/aac.48.1.15-22.2004.

29.Amudhan, S.M., Sekar, U., Arunagiri, K., Sekar, B. (2011). OXA beta-lactamase mediated carbapenem resistance in Acinetobacter baumannii. Indian J Med Microbio. 2011;29(3),269-274. doi: 10.4103 / 0255-0857.83911.

30.Ambler, R. P. The structure of beta-lactamases. Philosophical Transactions of the Royal Society Biological Sciences, London. 1980;289(36),321-331. doi: 10.1098/rstb.1980.0049.

31.Lima Barbieri N, Nielsen DW, Wannemuehler Y, Cavender T, Hussein A, Yan SG, Nolan LK, Logue CM. mcr-1 identified in Avian Pathogenic Escherichia coli (APEC). PLoS One. 2017;6;12(3):e0172997. doi: 10.1371/journal.pone.0172997.

32.Kara Ö, Zarakolu P, Aşçioğlu S, Etgül S, Uz B, Büyükaşik Y, Akova M. Epidemiology and emerging resistance in bacterial bloodstream infections in patients with hematologic malignancies. Infect Dis (Lond). 2015;47(10):686-93. doi: 10.3109/23744235.2015.1051105.

33.Gudiol C, Aguado JM, Carratalà J. Bloodstream infections in patients with solid tumors. Virulence. 2016;2;7(3):298-308. doi:

10.1080/21505594.2016.1141161.

34.Lubwama M, Phipps W, Najjuka CF, Kajumbula H, Ddungu H, Kambugu JB, Bwanga F. Bacteremia in febrile cancer patients in Uganda. BMC Res Notes. 2019;30;12(1):464. doi: 10.1186/s13104-019-4520-9.

35.Liang T, Xu C, Cheng Q, Tang Y, Zeng H, Li X. Epidemiology, Risk Factors, and Clinical Outcomes of Bloodstream Infection due to Extended-Spectrum BetaLactamase-Producing Escherichia coli and Klebsiella pneumoniae in Hematologic Malignancy: A Retrospective Study from Central South China. Microb Drug Resist. 2021;27(6):800-808. doi: 10.1089/mdr.2020.0033.

36.Abbasi Montazeri E, Khosravi AD, Saki M, Sirous M, Keikhaei B, Seyed-Mohammadi S. Prevalence of Extended-Spectrum Beta-Lactamase-Producing Enterobacteriaceae Causing Bloodstream Infections in Cancer Patients from Southwest of Iran. Infect Drug Resist. 2020;6;13:1319-1326. doi: $10.2147 /$ IDR.S254357.

37.Paul M, Bhatia M, Rekha US; Diksha 1, Omar BJ, Gupta P. Microbiological Profile of Blood Stream Infections in Febrile Neutropenic Patients at a Tertiary Care Teaching Hospital in Rishikesh, Uttarakhand. J Lab Physicians. 2020;12(2):147-153. doi: 10.1055/s-0040-1716661.

38.Patel HG, Tabassum S, Shaikh S. E. coli Sepsis: Red Flag for Colon Carcinoma-A Case Report and Review of the Literature. Case Rep Gastrointest Med. 2017:2570524. doi: 10.1155/2017/2570524.

39. Ota A, Morita S, Matsuoka A, Shimokata T, Maeda O, Mitsuma A, Yagi T, Asahara T, Ando Y. Detection of bacteria in blood circulation in patients receiving cancer chemotherapy. Int J ClinOncol. 2020;25(1):210-215. doi: 10.1007/s10147-019-01521-y. 
40.Bhat S, Muthunatarajan S, Mulki SS, Archana Bhat K, Kotian KH. Bacterial Infection among Cancer Patients: Analysis of Isolates and Antibiotic Sensitivity Pattern. Int J Microbiol. 2021;7;2021:8883700. doi: 10.1155/2021/8883700.

41.Ghosh S, Chakraborty M, Samanta S, Sinha N, Saha S, Chattopadhyay A, et al. Analysis of blood stream infections, antibiograms and clinical outcomes in haematological patients with febrile neutropenia: data from a tertiary care haematology institute in India. Ann Hematol. 2021;100(2):395-403. doi: $10.1007 /$ s00277-020-04324-8.

42.Diekema DJ, Hsueh PR, Mendes RE, Pfaller MA, Rolston KV, Sader HS, Jones RN. The Microbiology of Bloodstream Infection: 20-Year Trends from the SENTRY Antimicrobial Surveillance Program. Antimicrob Agents Chemother. 2019;24;63(7):e00355-19. doi: 10.1128/AAC.00355-19.

43.Sierra J, Díaz MV, de JesúsGarcía M, Finello M, Suasnabar DF, Richetta L, Toranzo A, Hernández D, Cometto MA, Vázquez SM, Caeiro JP, Saad EJ. Infecciones del torrente sanguine en pacientes oncológicos [Bloodstream infections in cancer patients]. Medicina (B Aires). 2020;80(4):329-338.

44.Royo-Cebrecos C, Gudiol C, Ardanuy C, Pomares H, Calvo M, Carratalà J. A fresh look at polymicrobial bloodstream infection in cancer patients. PLoS One. 2017;24;12(10):e0185768. doi: 10.1371/journal.pone.0185768.

45.Goldman S, Itshaki O, Shochat T, Gafter-Gvili A, Yahav D, Rubinovitch B, Shepshelovich D. Risk Factors and Outcome of Polymicrobial Bacteremia: A Retrospective Cohort Study. Isr Med Assoc J. 2020;22(5):279-284.

46.Agrawal SK, Gautam H, Choudhary AH, Das BK, Kumar L, Kapil A. Central Line-associated Bloodstream Infections in Cancer Patients: An Experience from a Tertiary Care Cancer Centre. Indian J Med Microbiol. 2019;37(3):376-380. doi: 10.4103/ijmm.IJMM_19_352.

47. Soares, CRP., Magalhães, V., Araújo, PSR. Coexistence of blaTEM, blaCTX, blaKPC, blaNDM, blaSIM e blaOXA-48 in polymicrobial bloodstream isolates from a patient with acute myeloid leukemia. Research, Society and Development, 2021;10(5)e39310514985. doi: 10.33448/rsd-v10i5.14985.

48.Carlesse F, Cappellano P, Quiles MG, Menezes LC, Petrilli AS, Pignatari AC. Clinical relevance of molecular identification of microorganisms and detection of antimicrobial resistance genes in bloodstream infections of paediatric cancer patients. BMC Infect Dis. 2016;1;16(1):462. doi: 10.1186/s12879-016-1792-8.

49.Fentie A, Wondimeneh Y, Balcha A, Amsalu A, Adankie BT. Bacterial profile, antibiotic resistance pattern and associated factors among cancer patients at University of Gondar Hospital, Northwest Ethiopia. Infect Drug Resist. 2018;8;11:2169-2178. doi: 10.2147/IDR.S183283.

50.Vahedian-Ardakani HA, Moghimi M, Shayestehpour M, Doosti M, Amid N. Bacterial Spectrum and Antimicrobial Resistance Pattern in Cancer Patients with Febrile Neutropenia. Asian Pac J Cancer Prev. 2019;25;20(5):1471-1474. doi: 10.31557/APJCP.2019.20.5.1471.

51.Islas-Muñoz B, Volkow-Fernández P, Ibanes-Gutiérrez C, Villamar-Ramírez A, Vilar-Compte D, Cornejo-Juárez P. Bloodstream infections in cancer patients. Risk factors associated with mortality. Int J Infect Dis. 2018;71:59-64. doi: 10.1016/j.ijid.2018.03.022.

52. Kang Cl, Chung DR, Ko KS, Peck KR, Song JH; Korean Network for Study of Infectious Diseases. Risk factors for infection and treatment outcome of extended-spectrum $\beta$-lactamase-producing Escherichia coli and Klebsiella pneumoniae bacteremia in patients with hematologic malignancy. Ann Hematol. 2012;91(1):115-21. doi: 10.1007/s00277-011-1247-7.

53.Zhang Q, Gao HY, Li D, et al. Clinical outcome of bloodstream infection by Escherichia coli in cancer patients with / without biofilm formation: a single center retrospective study. Infect Drug Resist. 2019;12:359-371. doi: 10.2147 / IDR.S192072

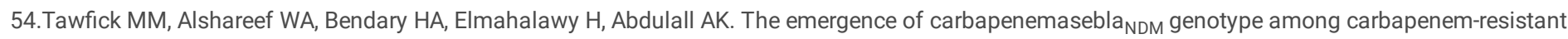
Enterobacteriaceae isolates from Egyptian cancer patients. Eur J ClinMicrobiol Infect Dis. 2020;39(7):1251-1259. doi: 10.1007/s10096-020-03839-2.

55.Satlin MJ, Calfee DP, Chen L, Fauntleroy KA, Wilson SJ, Jenkins SG, Feldman EJ, Roboz GJ, Shore TB, Helfgott DC, Soave R, Kreiswirth BN, Walsh TJ. Emergence of carbapenem-resistant Enterobacteriaceae as causes of bloodstream infections in patients with hematologic malignancies. Leuk Lymphoma. 2013;54(4):799-806. doi: 10.3109/10428194.2012.723210.

56.Nordmann P, Poirel L. Epidemiology and Diagnostics of Carbapenem Resistance in Gram-negative Bacteria. Clin Infect Dis. 2019;13;69(Suppl 7):S521S528. doi: 10.1093/cid/ciz824.

57.Tarafdar F, Jafari B, Azimi T. Evaluating the antimicrobial resistance patterns and molecular frequency of b/a $a_{\mathrm{Oxa}-48}$ and $b / a_{\mathrm{GES}-2}$ genes in Pseudomonas aeruginosa and Acinetobacter baumannii strains isolated from burn wound infection in Tehran, Iran. New Microbes New Infect. 2020;23;37:100686. doi: 10.1016/j.nmni.2020.100686.

58. Woodford N, Ellington MJ, Coelho JM, Turton JF, Ward ME, Brown S, Amyes SG, Livermore DM. Multiplex PCR for genes encoding prevalent OXA carbapenemases in Acinetobacter spp. Int J Antimicrob Agents. 2006;27(4):351-3. doi: 10.1016/j.ijantimicag.2006.01.004.

59.Hou C, Yang F. Drug-resistant gene of blaOXA-23, blaOXA-24, blaOXA-51 and blaOXA-58 in Acinetobacter baumannii. Int J Clin Exp Med. 2015;15;8(8):13859-63.

60.Sah R, Khadka S, Shrestha GS, Acharya S, Aryal D, Shrestha P, Kattel HP, Shah NP, Pokhrel BM, Singh YP, Rijal B, Erdem H. Detection of Pan drug resistance OXA-48 producing Providencia in an ICU patient for the first time in Nepal. Antimicrob Resist Infect Control. 2019;15;8:155. doi: 10.1186/s13756-019-0608-1.

Page $10 / 16$ 
61. Hashem H, Hanora A, Abdalla S, Shaeky A, Saad A. Dissemination of metallo- $\beta$-lactamase in Pseudomonas aeruginosa isolates in Egypt: mutation in blaVIM-4. APMIS. 2017;125(5):499-505. doi: 10.1111/apm.12669.

62. Santos AL, Dos Santos AP, Ito CRM, Queiroz PHP, de Almeida JA, de Carvalho Júnior MAB, de Oliveira CZ, Avelino MAG, Wastowski IJ, Gomes GPLA, Souza ACSE, Vasconcelos LSNOL, Santos MO, da Silva CA, Carneiro LC. Profile of Enterobacteria Resistant to Beta-Lactams. Antibiotics (Basel). 2020;15;9(7):410. doi: 10.3390/antibiotics9070410.

63. Jácome PRLA, Alves LR, Jácome-Júnior AT, Silva MJBD, Lima JLDC, Araújo PSR, Lopes ACS, Maciel MAV. Detection of blaSPM-1, blaKPC, blaTEM and blaCTX-M genes in isolates of Pseudomonas aeruginosa, Acinetobacter spp. and Klebsiella spp. from cancer patients with healthcare-associated infections. J Med Microbiol. 2016;65(7):658-665. doi: 10.1099/jmm.0.000280.

64.Monaco M, Pimentel de Araujo F, Cruciani M, Coccia EM, Pantosti A. Worldwide Epidemiology and Antibiotic Resistance of Staphylococcus aureus. Curr Top Microbiol Immunol. 2017;409:21-56. doi: 10.1007/82_2016_3.

65.Li Z, Zhuang H, Wang G, Wang H, Dong Y. Prevalence, predictors, and mortality of bloodstream infections due to methicillin-resistant Staphylococcus aureus in patients with malignancy: systemic review and meta-analysis. BMC Infect Dis. 2021;14;21(1):74. doi: 10.1186/s12879-021-05763-y.

66.Atmaca O, Zarakolu P, Karahan C, Cakır B, Unal S. Hacettepe Üniversitesi Erişkin ve Onkoloji Hastanelerinde yatan hastalarda saptanan metisiline dirençli Staphylococcus aureus bakteriyemilerinde risk faktörleri (2004-2011), antibiyotik kullanımı ve izolatların antimikrobiyal duyarılıkları: Yuvalandırılmış olgukontrol çalışması [Risk factors and antibiotic use in methicillin-resistant Staphylococcus aureus bacteremia in hospitalized patients at Hacettepe University Adult and Oncology Hospitals (2004-2011) and antimicrobial susceptibilities of the isolates: a nested case-control study]. Mikrobiyol Bul. $2014 ; 48(4): 523-37$. Turkish. doi: $10.5578 / \mathrm{mb} .8280$.

67.Amarnani R, Rapose A. Colon cancer and enterococcus bacteremia co-affection: A dangerous alliance. J Infect Public Health. 2017;10(5):681-684. doi: 10.1016/j.jiph.2016.09.009. Epub 2017 Jan 29.

68.Alves J, Palma P, Azevedo D, Rello J. Candidemia in the patient with malignancy. Hosp Pract (1995). 2018;46(5):246-252. doi:

$10.1080 / 21548331.2018 .1508290$.

69.Wu PF, Liu WL, Hsieh MH, Hii IM, Lee YL, Lin YT, Ho MW, Liu CE, Chen YH, Wang FD. Epidemiology and antifungal susceptibility of candidemia isolates of non-albicans Candida species from cancer patients. Emerg Microbes Infect. 2017;11;6(10):e87. doi: 10.1038/emi.2017.74.

70.Tang HJ, Liu WL, Lin HL, Lai CC. Epidemiology and prognostic factors of candidemia in cancer patients. PLoS One. 2014;5;9(6):e99103. doi: 10.1371/journal.pone.0099103.

71.Guo LN, Yu SY, Xiao M, Yang CX, Bao CM, Yu YH, Ye LY, Yang Y, Zhang G, Liu J, Liang GW, Min R, Zhu Y, Lei H, Liu YL, Liu LJ, Hu YJ, Hsueh PR, Xu YC. Species Distribution and Antifungal Susceptibility of Invasive Candidiasis: A 2016-2017 Multicenter Surveillance Study in Beijing, China. Infect Drug Resist. 2020;20;13:2443-2452. doi: 10.2147/IDR.S255843.

72.Shekari Ebrahim Abad H, Zaini F, Kordbacheh P, Mahmoudi M, Safara M, Mortezaee V. In Vitro Activity of Caspofungin Against Fluconazole-Resistant Candida Species Isolated From Clinical Samples in Iran. Jundishapur J Microbiol. 2015;27;8(6):e18353. doi: 10.5812/jjm.18353v2.

73.Chapman B, Slavin M, Marriott D, Halliday C, Kidd S, Arthur I, Australian and New Zealand Mycoses Interest Group. Changing epidemiology of candidaemia in Australia. J Antimicrob Chemother. 2017;1;72(4):1103-1108. doi: 10.1093/jac/dkw422.

74.Malani AN, Kerr LE, Kauffman CA. Voriconazole: How to Use This Antifungal Agent and What to Expect. Semin Respir Crit Care Med. 2015;36(5):786-95. doi: 10.1055/s-0035-1562903.

75.Cowen LE, Sanglard D, Howard SJ, Rogers PD, Perlin DS. Mechanisms of Antifungal Drug Resistance. Cold Spring Harb Perspect Med. 2014;10;5(7):a019752. doi: 10.1101/cshperspect.a019752.

76.Bibi M, Murphy S, Benhamou RI, Rosenberg A, Ulman A, Bicanic T, Fridman M, Berman J. Combining Colistin and Fluconazole Synergistically Increases Fungal Membrane Permeability and Antifungal Cidality. ACS Infect Dis. 2021;20. doi: 10.1021/acsinfecdis.0c00721.

77.Sharafutdinov, I.S. et al. Increasing Susceptibility of Drug-Resistant Candida albicans to Fluconazole and Terbinafine by $2(5 H)$-Furanone Derivative. Molecules. 2020;25(3):642. doi: 10.3390/molecules25030642

78.Berkow E.L., Lockhart S.R. Fluconazole resistance in Candida species: A current perspective. Infect. Drug Resist. 2017;10:237-245. doi: $10.2147 /$ IDR.S118892.

\section{Tables}

Adjusted according to the classification of $\beta$-lactamases by Ambler (1980) ${ }^{30}$.

Table 2. Profile of antimicrobial resistance in organisms isolated from infection in the bloodstream of cancer patients through automated testing using the vitek $2 \circledast$ platform. 
Table 1 - Sequence of primers of the carbapenemase resistance genes with the respective ringing temperatures and amplicon size.

\begin{tabular}{|c|c|c|c|c|c|}
\hline \multirow[t]{2}{*}{ Carbapenemases } & \multicolumn{3}{|c|}{$\begin{array}{l}\text { Genes of } \\
\text { Carbapenemases }\end{array}$} & \multirow{2}{*}{$\begin{array}{l}\text { Amplicon size in } \\
\mathrm{pb} \\
\qquad 60^{\circ} \mathrm{C}\end{array}$} & \multirow{2}{*}{$\begin{array}{c}\text { Temperature }(t) \quad \text { References } \\
{ }^{\circ} \mathrm{C} \\
\text { Menezes et al, } 2013^{24}\end{array}$} \\
\hline & $b / a_{\mathrm{KPC}-\mathrm{F}}$ & ATGTCACTGTATCGCCGTCTAGTTC & 800 & & \\
\hline \multirow[t]{7}{*}{ A Class } & $b / a_{\mathrm{KPC}-\mathrm{R}}$ & CAATCCCTCGAGCGCGAGTC & & & \\
\hline & bla $_{\text {GES-F }}$ & СTATTACTGGCAGGGATCG & 594 & $55^{\circ} \mathrm{C}$ & Monteiro, $2012^{25}$ \\
\hline & bla $_{\text {GES-R }}$ & ССTCTCAATGGTGTGGGT & & & \\
\hline & $b / a_{\mathrm{NDM}-\mathrm{F}}$ & CGGAATGGCTCATCACGATC & $580-605$ & $60^{\circ} \mathrm{C}$ & Nithia et al, $2017^{26}$ \\
\hline & $b / a_{\mathrm{NDM}-\mathrm{R}}$ & GGTTTGGCGATCTGGTTTTC & & & \\
\hline & $b / a_{\mid \mathrm{MP}-\mathrm{F}}$ & 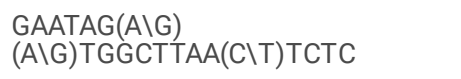 & 188 & $52^{\circ} \mathrm{C}$ & Mendes, $2007^{27}$ \\
\hline & $b / a_{\text {IMP-R }}$ & 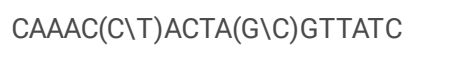 & & & \\
\hline \multirow[t]{8}{*}{ B Class } & $b / a_{\mathrm{VIM}-\mathrm{F}}$ & GTTTGGTCGCATATCGCAAC & 382 & $52^{\circ} \mathrm{C}$ & Mendes, $2007^{27}$ \\
\hline & bla ${ }_{\mathrm{VIM}-\mathrm{R}}$ & AATGCGCAGCACCAGGATAG & & & \\
\hline & $b / a_{\mathrm{SPM}-\mathrm{F}}$ & CTAAATCGAGAGCCCTGCTTG & 798 & $52^{\circ} \mathrm{C}$ & Mendes, $2007^{27}$ \\
\hline & $b / a_{\mathrm{SPM}-\mathrm{R}}$ & СCTTTTCCGCGACCTTGATC & & & \\
\hline & $b / a_{\mathrm{GIM}-\mathrm{F}}$ & TCAATTAGCTCTTGGGCTGAC & 72 & $55^{\circ} \mathrm{C}$ & Mendes, $2007^{27}$ \\
\hline & $b / a_{\mathrm{GIM}-\mathrm{R}}$ & CGGAACGACCATTTGAATGG & & & \\
\hline & $b / a_{\text {SIM-F }}$ & GTACAAGGGATTCGGCATCG & 569 & $55^{\circ} \mathrm{C}$ & Mendes, $2007^{27}$ \\
\hline & $b / a_{\text {SIM-R }}$ & TGGCCTGTTCCCATGTGAG & & & \\
\hline \multirow[t]{4}{*}{ D Class } & bla $_{\text {OXA-48-F }}$ & TTGGTGGCATCGATTATCGG & 743 & $52^{\circ} \mathrm{C}$ & Poirel et al, $2004^{28}$ \\
\hline & bla $_{O X A-48-R}$ & GAGCACTTCTTTTGTGATGGC & & & \\
\hline & bla $_{\text {OXA-58-F }}$ & AAGTATTGGGGCTTGTGCTG & 599 & $52^{\circ} \mathrm{C}$ & Amudhan et al, $2011^{29}$ \\
\hline & bla $_{\text {OXA-58-R }}$ & ССССТСTGCGCTCTACATAC & & & \\
\hline
\end{tabular}




\begin{tabular}{|c|c|c|}
\hline Resistance profile against antimicrobials & $\left(n^{\circ}\right)$ & $(\%)$ \\
\hline Gram-negatives & 38 & \\
\hline Acid. Nalidixic & 10 & $26,3 \%$ \\
\hline Ciprofloxacin & 13 & $34,2 \%$ \\
\hline Norfloxacin & 7 & $18,4 \%$ \\
\hline Amoxicillin/clavulanate & 3 & $7,9 \%$ \\
\hline Ampicilin/subactam & 4 & $10,5 \%$ \\
\hline Piperaciclin/tazobactam & 8 & $21 \%$ \\
\hline Cephalothin & 10 & $26,3 \%$ \\
\hline Cefepime & 15 & $39,4 \%$ \\
\hline Ceftriaxone & 10 & $26,3 \%$ \\
\hline Cefuroxime & 11 & $29 \%$ \\
\hline Cefoxitin & 1 & $2,6 \%$ \\
\hline Ceftazidime & 5 & $13 \%$ \\
\hline Amikacin & 6 & $15,7 \%$ \\
\hline Gentamycin & 9 & $23,6 \%$ \\
\hline Meropenem & 7 & $18,4 \%$ \\
\hline Imipenem & 4 & $10,5 \%$ \\
\hline Ertapenem & 2 & $5,2 \%$ \\
\hline Ampicillin & 24 & $63,15 \%$ \\
\hline Tigecycline & 4 & $10,5 \%$ \\
\hline Sulfamethoxazole/trimethoprim & 4 & $10,5 \%$ \\
\hline Gram-positive & 13 & \\
\hline Oxacillin & 6 & $46 \%$ \\
\hline Penicillin & 4 & $30,7 \%$ \\
\hline Erythromycin & 5 & $38,4 \%$ \\
\hline Clindamycin & 3 & $23 \%$ \\
\hline Sulfamethoxazole/trimethoprim & 3 & $23 \%$ \\
\hline Gentamycin & 4 & $30,7 \%$ \\
\hline Vancomycin & 1 & $7,7 \%$ \\
\hline Daptomycin & 0 & \\
\hline Tigecycline & 0 & \\
\hline Linezolid & 0 & \\
\hline Ceftaroline & 0 & \\
\hline
\end{tabular}


Table 3. Resistance profile against bacterial isolates in cancer patients.

\begin{tabular}{|c|c|c|c|c|c|c|}
\hline Gram-negatives & $\begin{array}{l}\text { (14) Escherichia } \\
\text { coli }\end{array}$ & (11)Klebsiella spp & $\begin{array}{l}\text { (7)Pseudomonas } \\
\text { spp }\end{array}$ & $\begin{array}{l}\text { (3) } \\
\text { Acinetobacter } \\
\text { baumannii }\end{array}$ & $\begin{array}{l}\text { (2) Serratia } \\
\text { marcencens }\end{array}$ & $\begin{array}{l}\text { (1) } \\
\text { Salmonel }\end{array}$ \\
\hline Acid. Nalidixic & $6(42,8 \%)$ & $2(18,2 \%)$ & & & $1(50 \%)$ & \\
\hline Amikacin & & & $3(42,8 \%)$ & & $2(100 \%)$ & $1(100 \%)$ \\
\hline Amoxicillin/clavulanate & & $1(9 \%)$ & & & $2(100 \%)$ & \\
\hline Ampicillin & $11(78,5 \%)$ & $11(100 \%)$ & & & $2(100 \%)$ & \\
\hline Ampicilina/sulbactam & $2(14,28)$ & $1(9 \%)$ & & $1(33,33 \%)$ & & \\
\hline Cephalothin & $4(28,5 \%)$ & $3(27,3 \%)$ & & & $2(100 \%)$ & $1(100 \%)$ \\
\hline Cefepime & $4(28,5 \%)$ & $4(36,3 \%)$ & $3(42,8 \%)$ & $2(66,6 \%)$ & $2(100 \%)$ & \\
\hline Ceftriaxone & $4(28,5 \%)$ & $4(36,3 \%)$ & & & $2(100 \%)$ & \\
\hline Cefuroxime & $4(28,5 \%)$ & $4(36,3 \%)$ & & & $2(100 \%)$ & $1(100 \%)$ \\
\hline Cefoxitin & & $1(9 \%)$ & & & & \\
\hline Ceftazidime & $1(7,14 \%)$ & $1(9 \%)$ & $2(28,6 \%)$ & $1(33,33 \%)$ & & \\
\hline Ciprofloxacin & $5(35,7 \%)$ & $3(27,3 \%)$ & $3(42,8 \%)$ & $2(66,6 \%)$ & & \\
\hline Ertapenem & & $1(9 \%)$ & & & $1(50 \%)$ & \\
\hline Gentamycin & $2(14,28 \%)$ & $2(18,2 \%)$ & $3(42,8 \%)$ & & & $1(100 \%)$ \\
\hline Meropenem & & $1(9 \%)$ & $3(42,8 \%)$ & $2(66,6 \%)$ & $1(50 \%)$ & \\
\hline Imipenem & & $1(9 \%)$ & $2(28,6 \%)$ & $1(33,33 \%)$ & & \\
\hline Norfloxacin & $4(28,5 \%)$ & $2(18,2 \%)$ & $1(14,3 \%)$ & & & \\
\hline Piperaciclin/tazobactam & & $2(18,2 \%)$ & $3(42,8 \%)$ & $2(66,6 \%)$ & $1(50 \%)$ & \\
\hline Tigecycline & & & $4(57,1 \%)$ & & & \\
\hline Sulfametoxazole/trimetoprim & $3(21,4 \%)$ & $1(9 \%)$ & & & & \\
\hline Gram-positives & $\begin{array}{l}\text { (5) Staphylococcus } \\
\text { aureus }\end{array}$ & $\begin{array}{l}\text { (6) Staphylococcus coagulase } \\
\text { negativo }\end{array}$ & $\begin{array}{l}\text { (1) Enterococcus } \\
\text { faecium }\end{array}$ & $\begin{array}{l}\text { (1) Enterococcus } \\
\text { faecalis }\end{array}$ & & \\
\hline Gentamycin & $2(40 \%)$ & $2(33,33 \%$ & & & & \\
\hline Sulfametoxazole/trimetroprim & $2(40 \%)$ & $1(16,6 \%)$ & & & & \\
\hline Clindamycin & $2(40 \%)$ & $1(16,6 \%)$ & & & & \\
\hline Erythromycin & $2(40 \%)$ & $3(50 \%)$ & & & & \\
\hline Oxacilin & $3(60 \%)$ & $3(50 \%)$ & & & & \\
\hline Penicilin & $2(40 \%)$ & $2(33,33 \%)$ & & & & \\
\hline Rifampicin & $1(20 \%)$ & $2(33,33 \%)$ & & & & \\
\hline Vancomycin & & & $1(100 \%)$ & & & \\
\hline Levofloxacin & $2(40 \%)$ & $1(16,6 \%)$ & & & & \\
\hline Ampicillin & & & $1(100 \%)$ & & & \\
\hline
\end{tabular}


Table 4. Detection of ESBL and MBL resistance genes in bloodstream isolates from cancer patients.

\begin{tabular}{|c|c|c|}
\hline ID & Pathogen & Genes \\
\hline $1 \mathrm{HCP} 334$ & Escherichia coli & SHV, TEM, KPC, NDM, IMP, GES, SIM, OXA-48 e OXA-58 \\
\hline 2HCP1243 & Escherichia coli & TEM, KPC, NDM, IMP, VIM, GES, SIM, OXA-48 E OXA-58 \\
\hline $2 \mathrm{HCP} 1121$ & & CTX, NDM, SPM, GES, SIM, OXA-48 \\
\hline 3НСР291 & Escherichia coli & TEM, KPC, NDM, IMP, VIM, GES, SIM, OXA-48 E OXA-58 \\
\hline 4 HCP649 & Escherichia coli & TEM, KPC, IMP, GES, SIM, OXA-48 E OXA-58 \\
\hline $5 \mathrm{HCP} 860$ & Escherichia coli & TEM, KPC, IMP, VIM, GES, SIM, OXA-48 E OXA-58 \\
\hline $6 \mathrm{HCP} 868$ & Klebsiellapneumoniae & TEM, KPC, IMP, VIM, GES, SIM, OXA-48 \\
\hline 7HCP1058 & Escherichia coli & TEM, CTX, NDM, VIM, GES, SIM, OXA-58 \\
\hline $8 \mathrm{HCP} 1112$ & Klebsiellapneumoniae & TEM, CTX, NDM, VIM, SPM, GES, SIM, OXA-48 E OXA-58 \\
\hline $8 \mathrm{HCP} 1112$ & Escherichia coli & TEM, CTX, NDM, VIM, GES, SIM, OXA-48 E OXA-58 \\
\hline 9HCP1118 & Pseudomonasaeruginosa & CTX, KPC, NDM, SPM \\
\hline $10 \mathrm{HCP} 1405$ & Klebsiellapneumoniae & CTX, NDM, GES, SIM, OXA-48 \\
\hline $12 \mathrm{HCP} 1060$ & Staphylococcuscoagulase Negativa & $\operatorname{mec} A$ \\
\hline 13НСР1401 & Serratiamarcescens & CTX, NDM, GES, SIM, OXA-48 \\
\hline $14 \mathrm{HCP} 1257$ & Klebsiellapneumoniae & TEM, CTX, GES, SIM, OXA-48 \\
\hline 15HCP1253 & Pseudomonasalcaligenes & SPM, SIM, OXA-48 \\
\hline 16HCP1191 & Staphylococcusepidermidis & $\operatorname{mec} A$ \\
\hline 17HCP1177 & Staphylococcus aureus & - \\
\hline 19HCP888 & Klebsiellapneumoniae & TEM, CTX, NDM, GES, SIM, OXA-48 \\
\hline $20 \mathrm{HCP} 7$ & Escherichia coli & SIM, OXA-48 \\
\hline 21HCP61 & Pseudomonasaeruginosa & SIM, OXA-48 \\
\hline 22HCP07 & Escherichia coli & TEM, CTX, NDM, SIM, OXA-48 \\
\hline 23HCP1251 & Pseudomonasaeruginosa & CTX, SPM, GES, SIM, OXA-48 \\
\hline 24HCP921 & Klebsiellaoxytoca & GES \\
\hline 25HCP796 & Staphylococcusepidermidis & - \\
\hline 26HCP127 & Staphylococcuswarneri & - \\
\hline 27HCP111 & Staphylococcus aureus & - \\
\hline 28HCP1168 & Acinetobacterbaumannii & SHV, TEM, SPM, GES, OXA-58 \\
\hline $29 \mathrm{HCР} 333$ & Serratiamarcescens & TEM, CTX, KPC, SPM, OXA-48, OXA-58 \\
\hline $30 \mathrm{HCP} 263$ & Klebsiellapneumoniae & CTX, KPC, NDM, GES, SIM \\
\hline $31 \mathrm{HCP} 478$ & Escherichia coli & TEM, OXA-48 \\
\hline $32 \mathrm{HCP} 467$ & Streptococcussalivarus & - \\
\hline 33НСР604 & Enterococcusfaecalis & $\operatorname{mec} A$ \\
\hline 34HCP682 & Escherichia coli & TEM, OXA-48 \\
\hline $35 \mathrm{HCP} 747$ & Pseudomonasaeruginosa & KPC, SIM, OXA-48 \\
\hline 36HCP835 & Salmonellagroup & OXA-48 \\
\hline 37HCP952 & Staphylococcus aureus & $\operatorname{mec} A$ \\
\hline 38НCP1326 & Acinetobacterbaumannii & TEM, OXA-48 \\
\hline 39НСР1336 & Klebsiellapneumoniae & TEM \\
\hline $40 \mathrm{HCP} 1220$ & Pseudomonasaeruginosa & TEM, SIM \\
\hline 40HCР1398 & Escherichia coli & TEM, OXA-48 \\
\hline
\end{tabular}

Page 15/16 


\begin{tabular}{lll} 
40HCP49 & Escherichia coli & TEM, CTX \\
\hline $40 \mathrm{HCP} 263$ & Klebsiellapneumoniae & CTX, KPC, NDM, SIM, OXA-48 \\
\hline $40 \mathrm{HCP} 419$ & Acinetobacterbaumannii & OXA-48 \\
\hline $41 \mathrm{HCP} 4$ & Enterococcusfaecium & VanA \\
\hline $42 \mathrm{HCP} 223$ & Staphylococcus aureus & mecA \\
\hline $43 \mathrm{HCP} 109$ & Staphylococcusepidermidis & mecA \\
\hline $44 \mathrm{HCP} 327$ & Klebsiellapneumoniae & SIM, OXA-48 \\
\hline $45 \mathrm{HCP} 480$ & Staphylococcus aureus & - \\
\hline $46 \mathrm{HCP} 526$ & Escherichia coli & TEM, CTX, NDM, GES, SIM OXA-48
\end{tabular}

Table 5- Antifungal susceptibility test for Candida spp. in isolates obtained from cancer patients.

\begin{tabular}{lllllllll}
\hline \multicolumn{7}{c}{ Antifungal treatment / MIC values $(\mu \mathrm{g} / \mathrm{ml})$} \\
\hline PT & Id & Strains & AMB & FLZ & VRZ & CPF & MCF & ANF \\
\hline $\mathbf{1}$ & 1047 & C. tropicalis & 0,03 & 32 & 16 & 0,06 & 0,03 & 0,03 \\
\hline $\mathbf{2}$ & 1173 & C. albicans & 0125 & 8 & 16 & 0,125 & 0,03 & 0,03 \\
\hline $\mathbf{3}$ & 1345 & C. tropicalis & 1 & 32 & 16 & 0,5 & 0,03 & 0,125 \\
\hline $\mathbf{4}$ & 539 & C. parapsilosis & 0,5 & 0,5 & 16 & 0,06 & 0,06 & 0,06
\end{tabular}

PT- patients. Id - identification code number. AMB - amphotericin B, FLZ - fluconazole, VRZ - voriconazole, CPF - caspofugin, MCF - micafugin, ANF anidulafugin.

\section{Supplementary Files}

This is a list of supplementary files associated with this preprint. Click to download.

- graph1.jpg 